http://dx.doi.org/10.18778/1508-1117.21.07

\author{
Kalina Wojciechowska
}

\title{
HORYZONT GEOGRAFICZNY EWANGELII MARKA
}

Zarys treści: Ewangelia Marka od XVIII wieku powszechnie uważana jest za najstarszą z ewangelii kanonicznych, a wśród ewangelii kanonicznych dodatkowo za najstarszą z tzw. ewangelii synoptycznych. Często też traktowana jest jako źródło bądź jedno ze źródeł dla tekstów Mateusza i Łukasza, którzy przekaz Markowy uzupełniają, skracają, a bardzo często też uściślają i poprawiają nie tylko pod względem stylistycznym, ale także rzeczowym - w tym historycznym i geograficznym. Współczesna biblistyka próbuje ustalić pochodzenie, przyczynę i zasadność tych korekt, biorąc pod uwagę zarówno etapy redakcji, struktury tekstu, jak i kompetencje odbiorcze oraz świadomość teologiczną, historyczną i geograficzną adresatów poszczególnych ewangelii.

Celem prezentowanego artykułu jest konfrontacja wzmianek topograficznych zawartych w Ewangelii Marka z rzeczywistymi danymi geograficznymi oraz wskazanie funkcji, jakie wzmianki te pełnią w strukturze i kompozycji utworu oraz w jego teologicznym przesłaniu. Podstawowym materiałem badawczym jest grecki tekst Ewangelii wraz z aparatem krytycznym (NA 28); dominantę metodologiczną stanowi krytyka redakcji (redaction criticism) wraz $\mathrm{z}$ analizą lingwistyczną.

Słowa kluczowe: Ewangelia Marka, topografia, Galilea, Judea, Kafarnaum, Geraza, Tyr, Sydon, Jezioro Galilejskie, Jezus, misja, Jerozolima, Jordan.

\section{Ewangelia Marka - podstawowe informacje}

Przyjmuje się, że Ewangelia Marka powstała przed rokiem 70, a więc przed zburzeniem świątyni jerozolimskiej przez wojska Tytusa Flawiusza (przyszłego cesarza). Tekst miał być gotowy jeszcze za życia apostołów Piotra i Pawła lub tuż po ich śmierci. Nie wiadomo dokładnie, gdzie powstała - różne tradycje podają różne miejsca: Rzym, Aleksandrię, Syrię (Czerski 2003, s. 149-151). Jedno jest pewne - nie powstała na terenie Palestyny, a jej odbiorcami nie byli chrześcijanie żydowskiego pochodzenia. Ze świadectw zewnętrznych, pozabiblijnych wynika, że była skierowana do chrześcijan wywodzących się z Rzymian, związanych w jakiś sposób z rzymskim prawem i militariami, co zresztą znajduje potwierdzenie $\mathrm{w}$ tekście samej ewangelii z licznymi latynizmami odnoszącymi się do tych właśnie dziedzin życia (Czerski 2003, s. 136). 
Nie wiadomo dokładnie, kim jest autor tej ewangelii. Nadanie anonimowemu tekstowi imienia Marka musiało mieć miejsce na przełomie I i II wieku, wcześniej tekst funkcjonował najprawdopodobniej jako „wspomnienia Piotra”. Taka nazwa nie jest przypadkowa, ponieważ bardzo wcześnie uznano autora ewangelii za towarzysza, sekretarza, thumacza apostoła Piotra, który nie po kolei - jak powiada Papiasz - ale dokładnie spisał to, co głosił Piotr (Wojciechowska 2006, s. 27-29). Kim był zatem ów sekretarz? Jeśli przyjąć, że to rzeczywiście ten Marek, który towarzyszył Piotrowi, to kilka informacji o nim da się wyselekcjonować na podstawie Nowego Testamentu. W wielkim skrócie można stwierdzić, że Jan Marek, wymieniany w Dz i listach apostolskich, był chrześcijaninem pochodzenia żydowskiego, mieszkającym w Jerozolimie, dość majętnym i wykształconym. Jednocześnie - na co wskazuje jego imię pochodzenia łacińskiego Marcus (gr. Markos) - miał powiązania ze światem rzymskim i to najprawdopodobniej ze środowiskiem wojskowym ${ }^{1}$. To wszystko znajduje swoje odzwierciedlenie w przypisywanej mu ewangelii, także w tym, jak został zarysowany „horyzont geograficzny” jego wersji życia Jezusa.

Jeśli prześledzi się wzmianki topograficzne w Ewangelii Marka, to łatwo zauważyć, że nie są one wszędzie traktowane w ten sam sposób i wbrew pozorom nie wszystkie ułatwiają rekonstrukcję swoistego itinerarium Jezusa. Ze względu na dokładność, obrazowość i supozycje poczynione przez Marka, jego ewangelię można podzielić na cztery części:

1. Mk 1,1-6,29 - od początku działalności misyjnej Jezusa do rozesłania uczniów i śmierci Jana Chrzciciela.

2. Mk 6,30-9,1 - od powrotu uczniów do wyznania Szymona Piotra, kim jest Jezus (i cały rozbudowany kontekst towarzyszący temu wyznaniu).

3. Mk 9,2-11,11 - od przemienienia Jezusa na „wysokiej górze” do uroczystego wjazdu do Jerozolimy.

4. Mk 11,12-16,8 - ostatnie dni życia Jezusa, Jego proces, męka, ukrzyżowanie i zmartwychwstanie.

\section{Misja w Galilei}

W części pierwszej (Mk 1,1-6,29) wymienionych jest kilka nazw miejscowych, opisy pozwalają na identyfikację innych; np. 1,9-13, miejsce, w którym Jan dokonywał chrztu i bliskość pustyni, gdzie Jezus był kuszony, pozwala przypuszczać, że opisywane wydarzenia rozgrywają się na terenie Arabah (Wadi Araba) (McCown 2012, s. 3). Sama nazwa mówi, że jest to miejsce puste/ pustynne i suche. Skoro zszedł tam Jezus z Nazaretu i schodziła się tam cała Judea oraz mieszkańcy Jerozolimy (Mk 1,5), musiało być to miejsce położone

\footnotetext{
${ }^{1}$ Szerzej o Marku zob. K. Wojciechowska (2006, s. 22-42).

${ }^{2}$ Podział zaczerpnięty z: C.C. McCown (2012, s. 2-7).
} 
stosunkowo niedaleko Jerozolimy oraz Pustyni Judzkiej (Mk 1,4), najprawdopodobniej w północnej części Arabah, tam, gdzie Jordan wpływa do Morza Martwego. I rzeczywiście - jako to miejsce wskazuje się dziś Kasr al-Jahud, gdzie Jordan jest dość płytki (rys. 1).

Przez jakiś czas Jezus musiał pozostawać w tych okolicach, skoro następny epizod z danymi geograficznymi (Mk 1,14) mówi, że po uwięzieniu Jana Chrzciciela - a według Józefa Flawiusza (Dzieje dawnego Izraela XVIII 5,2) miało to miejsce w twierdzy Macheront, położonej na pustynnym wzgórzu zaledwie kilka kilometrów od wschodnich wybrzeży Morza Martwego - Jezus przybył do Galilei. Głównym ośrodkiem galilejskiej misji Jezusa staje się miejscowość rybacka Kafarnaum. To z Kafarnaum Jezus udaje się w bliższe bądź nieco dalsze okolice, by nauczać i czynami - uzdrowieniami połączonymi z odpuszczaniem grzechów - świadczyć o nastaniu królestwa Bożego: Pójdźmy gdzie indziej, do sasiednich miejscowości, abym i tam nauczat (...) i chodzit po całej Galilei, nauczajac w ich synagogach i wyrzucajac demony (Mk 1,38-39) ${ }^{3}$. Jest pewna trudność z ustaleniem nie tylko lokalizacji tych sąsiednich miejscowości oraz trasy tych krótkich, jedno-, dwu-, może trzydniowych podróży, ale również chronologii misyjnych wypraw Jezusa. Hagiograf bowiem bardzo oszczędnie dawkuje dane geograficzne (w ogóle stwierdzenia: sąsiednie miejscowości, cała Galilea lub zaimkowe ekwiwalenty dookreśleń - tam, synagogi ich) i chronologiczne, a poszczególne epizody łączy spójnikiem kai, czyli „i” oraz przysłówkiem euthys - „wtedy”, którego jednak nie należy traktować dosłownie jako wyznacznika czasu, ponieważ okazałoby się, że wszystko rozgrywa się równolegle. Dobrą ilustracją jest ciąg dalszy cytowanego już fragmentu: Chodzit po całej Galilei, nauczajac $w$ ich synagogach $i$ wyrzucajac demony. Wtedy podszedt do Niego trędowaty (Mk 1,40). Nie wiadomo, kiedy i nie wiadomo, gdzie miało miejsce to uzdrowienie. Po uzdrowieniu Jezus nakazał oczyszczonemu człowiekowi, by nie rozpowiadał o tym cudzie. Zakaz okazał się nieskuteczny: Lecz on wyszedt i zacząt opowiadać wkoło o tym wydarzeniu. Dlatego Jezus nie mógł jawnie wejść do miasta (jakiego miasta, nie wiadomo; uwaga K.W.), lecz przebywat w miejscach ustronnych ${ }^{4}$. Ludzie natomiast schodzili się do niego ze wszystkich stron” (Mk 1,45). Jedno jest pewne miastem tym nie było Kafarnaum, ponieważ od powrotu do Kafarnaum rozpoczyna się rozdział drugi Markowej ewangelii.

\footnotetext{
${ }^{3}$ Wszystkie tłumaczenia tekstów biblijnych oraz podkreślenia pochodzą od autorki artykułu.

${ }^{4}$ Greckie wyrażenie eremos topos może oznaczać zarówno miejsce ustronne, jak i miejsce pustynne. Trudno jednak przypuszczać, aby autorowi biblijnemu chodziło w tym miejscu o pustynię, ponieważ Galilea należała do najżyźniejszych i najbardziej urodzajnych terenów Palestyny.
} 


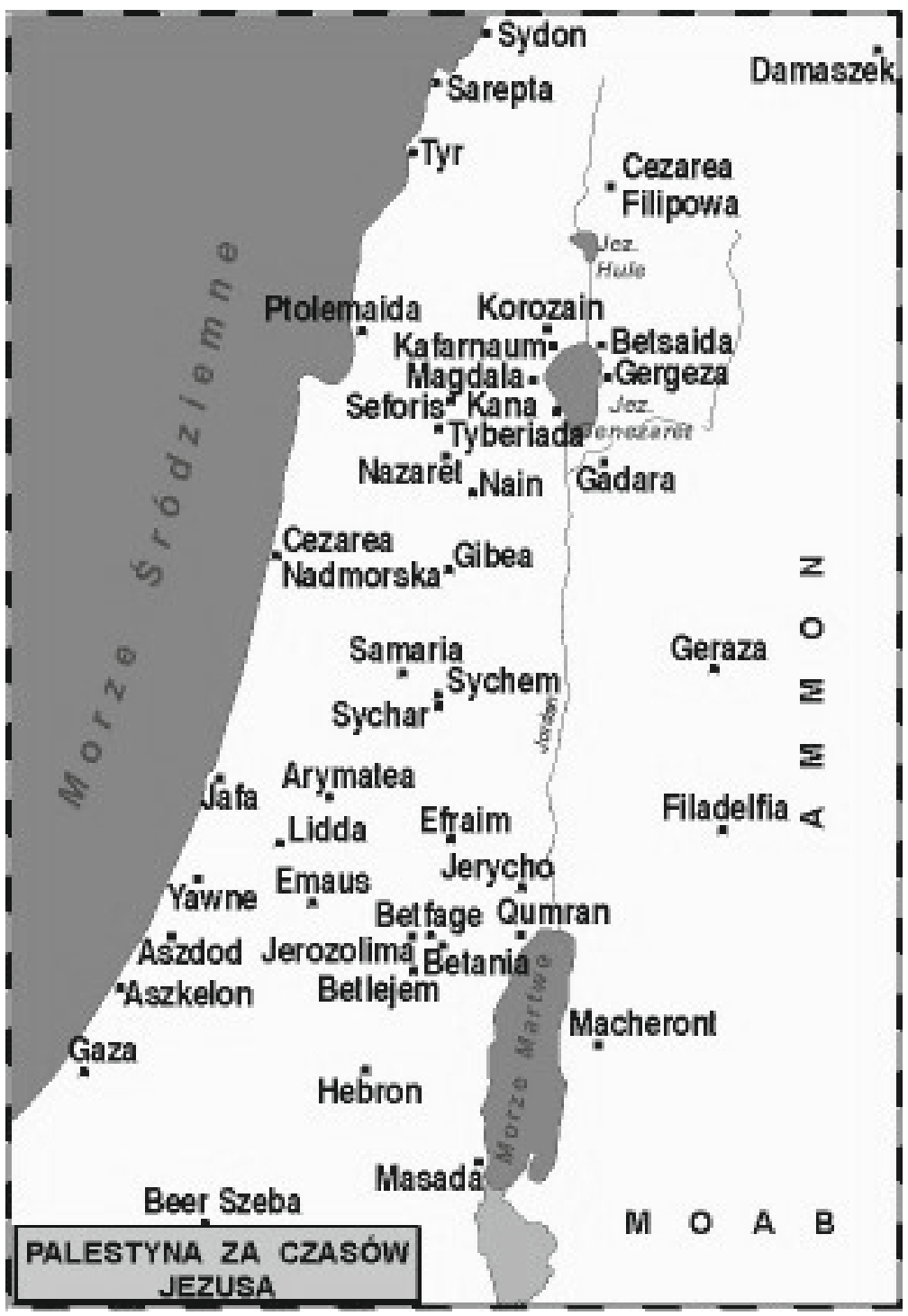

Rys. 1. Palestyna w czasach Jezusa

Źródło: http://casimir.kuczaj.free.fr/Polski/Swiat\%20Biblii/ swiat_biblijny.htm (dostęp: 6.06.2015)

Wiadomo, że opisana wyżej misyjna podróż trwała kilka dni - Kiedy po kilku dniach ponownie wszedt do Kafarnaum (Mk 2,1) - ale nie da się wyciągnąć żadnych wniosków, czy trwała kilka dni dlatego, że Jezus tak bardzo oddalił się od Kafarnaum, czy może dlatego, że dłużej zatrzymywał się w miejscach w pobliżu Kafarnaum. 
W tej pierwszej części hagiograf wielokrotnie wspomina o nauczaniu Jezusa nad jeziorem. Chodzi oczywiście o jezioro Genezaret, zwane też jeziorem lub Morzem Galilejskim, ponieważ grecki termin thalassa odnosi się zarówno do jeziora, jak i do morza. O ile taka dwuznaczność występuje w tekście Marka i Mateusza (obaj używają określenia thalassa tes Galilaias), o tyle Łukasz nie pozostawia wątpliwości, że chodzi o jezioro i używa nie tylko terminu limne, ale też nazwy Genezaret (limne Gennesaret - np. Łk 5,1). Uściślenia można znaleźć również w Ewangelii Jana, gdzie pojawia się fraza thalassa tes Galilaias tes Tiberiados - Jezioro Galilejskie czyli Tyberiadzkie (J 6,1). Jeśli zatem Jezus wyprawiał się nad jezioro z Kafarnaum, a w dodatku schodziły się do niego tłumy z Galilei i Judei, z Jerozolimy, Idumei, z Zajordania oraz z okolic Tyru i Sydonu (Mk 3,8), to opisywane wydarzenia musiały rozgrywać się u północno-zachodnich brzegów jeziora. W tamtej okolicy trzymano też łódź, do której Jezus wsiadał, gdy napierający tłum stawał się coraz bardziej natarczywy i niebezpieczny. Stamtąd Jezus wraz z uczniami wyruszył, by przeprawić się na drugi brzeg (Mk 4,35). W czasie tej przeprawy, która, jak się okazuje, wymagała wypłynięcia na środek jeziora, nastała gwałtowna burza, uciszona skutecznie przez Jezusa (Mk 4,37-41).

Przeprawa przez jezioro Genezaret jest tu szczególnie ważna, ponieważ nazwa miejsca, dokąd udał się Jezus, i niepewna, problematyczna identyfikacja stanowi jeden $\mathrm{z}$ najczęstszych argumentów potwierdzających nieznajomość topografii Palestyny przez ewangelistę. Chodzi o „krainę Gerazeńczyków” (Mk 5,1) (Funk 1998, s. 79).

Kraina Gerazeńczyków (gr. hora ton Gerasenon) miałaby się znajdować w pobliżu Jeziora Galilejskiego, o czym świadczy nie tylko wzmianka o przybyciu Jezusa do tego kraju, ale też spektakularne zakończenie cudu tam dokonanego - samobójstwo stada świń, które rzuciły się z urwiska do jeziora: Wtedy - wyszedtszy [z opętanego] - duchy nieczyste weszly w świnie. Trzoda liczaca około dwóch tysięcy ruszyła po urwisku do jeziora $i$ utonęła $w$ jeziorze (Mk 5,13). Tymczasem starożytna Geraza znajduje się ok. $60 \mathrm{~km}$ od jeziora, na terenie Dekapolis, zdominowanym rzeczywiście przez ludność nieżydowską. Tę Markową nieścisłość wyłapali już pozostali synoptycy - Mateusz i Łukasz. Mateusz, piszący do chrześcijan pochodzenia żydowskiego, dobrze orientujących się zapewne w geografii Palestyny, zmienia nazwę miejsca i mówi o „kraju Gadareńczyków” (gr. chora ton Gadarenon Mt 8,28). Lukasz piszący dla helleno-chrześcijan, nazwy co prawda nie zmienia ( $Ł k$ 8,26), ale dodaje, że kraina ta leżała „naprzeciw Galilei” (hestis estin antipera tes Galilaias).

Korekta Mateusza wydaje się zasadna. Starożytna Gadara leżała bowiem w odległości ok. $10 \mathrm{~km}$ od Jeziora Galilejskiego, a Józef Flawiusz zarówno w Wojnie Żydowskiej (I, 8,5), jak i w Dawnych dziejach Izraela (XIV, 5,4) wspomina, że obszar Gadary, a więc kraj lub okolica ${ }^{5}$ tego miasta, rozciągał się

\footnotetext{
${ }^{5}$ Gr. chora można tłumaczyć zarówno jako kraj, kraina, jak i okolica.
} 
aż do brzegów Jeziora Galilejskiego. Sama nazwa Gadara mogła ponadto odnosić się do miasta i do sporego okręgu administracyjnego - szeroko pojętej okolicy właśnie. Inne świadectwo Flawiusza (Autobiografia IX, 42) pozwala na jeszcze bliższą lokalizację okolic Gadary. Flawiusz mianowicie podaje, że wsie należace do Gadary i Hippos polożone [były] na pograniczu Tyberiady i ziemi Scytopolian, a więc rzeczywiście na południowo-wschodnim brzegu jeziora Genezaret. Związki Gadary z jeziorem potwierdzają monety z przedstawieniami statków znalezione w tym mieście (Langkammer 1977, s. 160).

Łukaszowy dodatek która jest naprzeciw Galilei, mimo że ewangelista pozostawia toponomię Marka, też koresponduje ze świadectwem Józefa Flawiusza. Jeśli Geraza miałaby leżeć naprzeciw Galilei, to należałoby jej szukać na wschodnim brzegu jeziora, właśnie w okolicach Hippos. Dlatego niektórzy bibliści identyfikują Gerazę z Kursi (lub okolicami); potwierdzeniem tej lokalizacji miałyby być świadectwa tekstu $\mathrm{NT}^{6}$, gdzie zamiast chora ton Gerasenon pojawia się wariant chora ton Gergesenon. O ile, stosując zasady greckiego słowotwórstwa, da się z określenia Gergesenoi - Gergezeńczycy wyprowadzić nazwę miasta - Gergeza, o tyle o takim mieście nie ma żadnych wzmianek ani z czasów Jezusa, ani z czasów Marka. Dlatego podejrzewa się, że w niektórych greckich odpisach Ewangelii Łukasza zhellenizowano w ten sposób aramejskie wyrażenie ger gezej oznaczające obcych (czyli pogan) z tamtej strony (czyli naprzeciw Galilei, z drugiej strony jeziora Genezaret) (Wojciechowski 2010, s. 90). Topografia - groty, góry, wzgórza również odpowiadałaby terytorium w pobliżu Hippos, tym bardziej, że ewangeliści wspominają, że stado świń się utopiło. Świnie potrafią pływać, gdyby brzegi jeziora były łagodne, zwierzęta na pewno by się uratowały (Wojciechowski 2010, s. 91). Natomiast wysokie urwiska skutecznie uniemożliwiły wydostaniu się zwierząt na ląd (Nineham 1969, s. 153).

Po dokonaniu cudu, Jezus znów przeprawił się łodzią do Galilei. I znów hagiograf nie podaje, do jakiego miasta. Nie wiadomo więc, gdzie nastąpiło uzdrowienie/wskrzeszenie córki Jaira i gdzie zdrowie odzyskała kobieta cierpiąca na krwotok. Jedynym tropem jest obecność synagogi w mieście. Najprawdopodobniej nie było to jednak Kafarnaum, bo Marek wymienia tę nazwę za każdym razem, gdy Jezus udaje się do miasta, pozostaje w nim lub je opuszcza. Będąc już po galilejskiej stronie jeziora, Jezus udaje się do swojego rodzinnego miasta - Nazaretu. Nieudana misja w Nazarecie kończy się bardzo ogólnym summarium: Dziwit się też ich niedowiarstwu. Potem obchodzil okoliczne wsie i nauczat $(\mathrm{Mk} 6,6)$.

${ }^{6}$ Lekcję Gergesenon zawierają m.in. druga korekta kodeksu Synajskiego (a), kodeksy Regius (L) z VIII wieku, Sangalleński (D) i Coridethi (Q), oba z IX wieku, część kodeksów minuskułowych powstałych po IX wieku, ponadto thumaczenia syryjskie, koptyjskie bohairyckie, armeńskie, etiopskie, gruzińskie, słowiańskie. 
Kolejny epizod tej części traktuje o rozesłaniu uczniów. Wiadomo, że Jezus rozsyła ich po dwóch, wiadomo, w jakie moce ich wyposaża, wiadomo, co uczniowie mogą ze sobą zabrać, a czego nie, wiadomo, jak mają się zachowywać w gościnie. Nie wiadomo jednak, skąd, z jakiego miasta czy wioski zostali wysłani i nie wiadomo, dokąd zostali wysłani (Mk 6,7-12). W przeciwieństwie do Mateusza, który dodaje tutaj zakaz pełnienia misji na terenach samarytańskich (Mt 10,5-6), ani Marek, ani Łukasz takiego zastrzeżenia nie przekazują. Być może wskazówką, dokąd udali się uczniowie, jest pojawiający się nagle opis ostatnich chwil Jana Chrzciciela, poprzedzony wzmianką, że król Herod ustyszat o Nim [o Jezusie] (Mk 6,14). Jak wspomniano, za miejsce egzekucji Jana uważa się twierdzę Macheront, leżącą na wschód od wybrzeży Morza Martwego. Górną część twierdzy stanowił pałac królewski, niżej mieściły się zabudowania obronne. Całość - wraz z otaczającymi twierdzą koszarami - otoczona była murami i tworzyła coś w rodzaju warownego miasta (Rosik b.r.w. Macheront). Herod zatem - jak sugeruje Marek - usłyszał o Jezusie, Jego nauczaniu i cudach wtedy, gdy przebywał w fortecy, w której dekapitowano Jana Chrzciciela. A to z kolei wskazywałoby, że misja uczniów sięgała poza Galileę, do Perei na południowym wschodzie. Warto przy tym zauważyć, że Pereę i Samarię oddzielał od siebie Jordan, a skoro uczniowie od razu udali się do Perei, zakaz, by nie przechodzili przez Samarię, wydaje się tu niepotrzebny. Rekonstrukcja trasy podróży misyjnej uczniów z Galilei poprzez Dekapolis do Perei wydaje się przekonująca także dlatego, że zostanie później powtórzona przez Jezusa wędrującego z Galilei do Judei (Mk 10,1) ${ }^{7}$.

Zasadniczym pytaniem pozostaje, dlaczego $\mathrm{w}$ tej części swojej ewangelii Marek tak nieprecyzyjnie podaje dane topograficzne, co widać zwłaszcza przy odniesieniach do Gerazy/Gadary/Gergezy? Odpowiedzi może być kilka. Po pierwsze, hagiografa interesuje przede wszystkim to, co Jezus robi i czego naucza, a nie przywiązuje wagi do tego, kiedy i gdzie miałoby się to odbywać. Po drugie - jak twierdzi G. Theissen (1992, s. 242-245) - błędy i nieścisłości popełniane przez ewangelistę są typowe dla środowisk, które nie posługują się na co dzień mapami. Tę sugestię zdaje się potwierdzać H.C. Kee (1977, s. 103), który przypuszcza, że Marek znał - być może od Piotra - tylko nazwy miejsc, a ponieważ nie posługiwał się mapą, nie potrafił dokładnie ich zlokalizować i podawał bardzo przybliżone usytuowanie. Konkretne nazwy zaś traktował jako punkty orientacyjne. Precyzyjna lokalizacja nie była istotna również z punktu widzenia odbiorców ewangelii - Rzymian, którzy o topografii Palestyny mieli znikome pojęcie. Orientowali się tylko - przynajmniej ogólnie - w administracji prowincji. Dlatego więc Marek wymienia Gerazę, która, jak wspomniano, była znanym miastem i ośrodkiem administracyjnym terytorium zamieszkanego przez zhellenizowaną, nieżydowską ludność. Podobnie będzie później z Dekapolis czy określeniem nieżydowskiej kobiety mianem Syrofenicjanki

\footnotetext{
${ }^{7}$ Por. niżej - część trzecia.
} 
i Greczynki - pierwszy termin odnosiłby się do podziału administracyjnego (Fenicja syryjska), drugi do kultury (kultura hellenistyczna). Nazwy niewielkich miejscowości, takich jak Gadara czy ewentualnie Gergeza, nic odbiorcom Markowej ewangelii nie mówiły. Trzeba też pamiętać, że Marek nie odtwarza żadnego dziennika podróży Jezusa (McCown 2012, s. 3), zapisuje to, co opowiadał apostoł Piotr, rybak z Galilei, od którego trudno byłoby wymagać doskonałej znajomości topografii. Zresztą - jak twierdzi H.-M. Schenke znajomość topografii Galilei była też znikoma wśród mieszkańców Judei, a zwłaszcza Jerozolimy (za: B.J. Incigneri 2003, s. 97), dlatego Marek nie zauważa być może i nie koryguje nieścisłości Piotra. Wyeksponowanie Kafarnaum w tej części ewangelii jest ponadto pewnym ukłonem hagiografa w stronę Piotra, który bowiem najprawdopodobniej stamtąd pochodził, tam się ożenił, tam mieszkała jego teściowa, tam też wielokrotnie udzielał Jezusowi gościny. W tym świetle zrozumiała jest polemika Papiasza $\mathrm{z}$ tymi, którzy zarzucają Markowi brak spójności chronologicznej i geograficznej.

\section{Między Żydami a poganami}

Motywem przewodnim części drugiej (Mk 6,30-9,1) wydaje się chęć ucieczki Jezusa przed thumem domagającym się cudów i wycofanie wraz z uczniami w miejsca ustronne. Często więc powtarza się tu fraza „miejsce odludne” lub „miejsce ustronne” (gr. eremos topos), co nie znaczy, że wcześniej określenie to nie było używane ${ }^{8}$. Ma się również wrażenie, że określenia topograficzne aczkolwiek też bardzo ogólne - pozwalają wyznaczyć trasę czy trasy podróży misyjnych Jezusa (McCown 2012, s. 4), choć czasem te trajektorie mogą budzić co najmniej zdziwienie.

Część ta rozpoczyna się od powrotu uczniów. Nie podano, gdzie zebrali się uczniowie po misji, ani jak długo ona trwała. Jest za to zalecenie Jezusa, aby uczniowie udali się na „miejsce ustronne”, by tam odpocząć. Na to miejsce uczniowie wyprawiają się łodzią, aby odizolować się od podążających za nimi tłumów. Nie mogą jednak płynąć daleko od brzegu, skoro ich widziano i brzegiem podążano w tym samym kierunku: Wielu to zauważyto. Przybyli więc tam [na miejsce ustronne] pieszo ze wszystkich miast, nawet ich [uczniów] wyprzedzając (Mk 6,33). Podobnie jak w części poprzedniej, Marek nie precyzuje, o jakie miasta chodzi, i podobnie jak poprzednio hiperbolizuje przekaz odnoszący się do zasięgu nauczania Jezusa (por. cała Judea, wszyscy mieszkańcy Jerozolimy, cata Galilea, wszystkie miasta). Opisywane dalej wydarzenia (rozmnożenie chleba i nakarmienie pięciu tysięcy mężczyzn - Mk 6,35-44) rozgrywają się prawdopodobnie na północno-zachodnich brzegach Jeziora Galilejskiego, na równinie Genezaret. O tym, że pierwszy cud rozmnożenia chleba miał

\footnotetext{
${ }^{8}$ Por. przypis 4.
} 
miejsce na równinie Genezaret, świadczy też nietypowa wzmianka o thumach siadających na zielonej trawie (Mk 6,39). Zielona trawa wydaje się tutaj synonimem urodzajności i żyzności charakterystycznych dla tych terenów. Po nakarmieniu thumu uczniowie usiłują przedostać się na drugi brzeg, czyli do Betsaidy (Mk 6,45).

Pozostawienie w tekście semickiej nazwy Betsaida (dosł. dom rybaka) w odniesieniu do miejscowości, która od ok. 30 r. n.e. nosiła nazwę Julias, nadaną jej przez Heroda Filipa na cześć żony cezara Augusta - jak donosi Józef Flawiusz (Dawne dzieje Izraela XVIII 2,11; 8,6), jest z jednej strony wyrazem szacunku, jaki Marek chce okazać Piotrowi, który najprawdopodobniej pochodził z tego miasta. Z drugiej - może być pewnym zabiegiem literackim, który ma na celu budowanie semickiego klimatu opowiadania i tworzenie analogii pomiędzy wydarzeniami rozgrywającymi się po zachodniej, zamieszkanej przez Żydów stronie Jeziora Galilejskiego i wydarzeniami mającymi miejsce po stronie wschodniej, zamieszkanej przez ludność zhellenizowaną ${ }^{9}$. Z perspektywy rzymskich odbiorców Markowej ewangelii bardziej naturalne byłoby posługiwanie się rzymską nazwą, zwłaszcza że Julias było miastem o wiele znaczniejszym pod względem kulturowym i politycznym niż np. Kafarnaum, skoro tam pochowany został Herod Filip (Briks 2004, s. 16), i jako mocno zhellenizowane, a wręcz zromanizowane, na pewno dobrze znane było adresatom Markowego tekstu. W Mk 6,45 Betsaida nie ma żadnego dookreślenia typu miasto, wieś, okolica, terytorium itp. Podobnie w Mk 6,53. Zaskakujące dookreślenie - wieś (gr. kome) - pojawia się dopiero w Mk 8,23 ${ }^{10}$. Z Betsaidy uczniowie wraz z Jezusem powrócili do ziemi (na równinę) Genezaret, co tym razem zostało w tekście wyeksplikowane (Mk 6,53). Trasa ich podroży wiodła więc z równiny Genezaret do Betsaidy i z powrotem na równinę Genezaret.

Dalsza misja Jezusa opisana jest w typowy dla Marka nieprecyzyjny sposób: Dokadkolwiek się udawat, czy to do wsi, czy do miast, czy też do osad, ktadli chorych na placach i prosili go, by im pozwolit dotknąc choć frędzli Jego płaszcza (Mk 6,56). Można zatem przypuszczać, że żadne z tych miast nie pełniło znaczących funkcji administracyjnych, nie stanowiło punktu odniesienia dla odbiorców, nie było też żadnego powodu, aby któreś z nich wyróżniać. Kontekst pozwala przypuszczać, że w tym summarium hagiografowi chodzi o obszar całej Galilei.

Stamtąd, czyli z Galilei (być może obszar ten można ograniczyć do terenów północnej Galilei) Jezus znów udał się na terytorium pogan, tym razem w okolice Tyru (Mk 7,24). Kilka rękopisów dodaje w tym miejscu jeszcze Sydon, są to więc okolice Tyru i Sydonu, a tekst zostaje zharmonizowany z Mk 3,8, gdzie była mowa o tłumach przychodzących właśnie z okolic Tyru i Sydonu. Z perspektywy krytyki tekstu bardziej oryginalna wydaje się jednak wersja z samym

\footnotetext{
9 Por. niżej.

${ }^{10}$ Por. niżej.
} 
Tyrem i jego terytoriami (gr. horia Tyrou ), co oznacza wkroczenie Jezusa do innej prowincji rzymskiej - Fenicji Syryjskiej. Wzmianka o Tyrze ma prawdopodobnie taki sam charakter jak wcześniejsza wzmianka o Gerazie - stanowi dla odbiorców pewien punkt odniesienia, a nie informację, gdzie dokładnie udał się i zatrzymał Jezus.

Po uzdrowieniu dziecka Syrofenicjanki Jezus odbywa - jak mówią niektórzy bibliści - bardzo dziwną podróż: I znowu wyszedtszy z terytoriów Tyru, poszedt przez Sydon nad Jezioro Galilejskie pośród terytoriów Dekapolis - tak brzmi dosłownie tekst grecki (Mk 7,31). Nawet jeśli uznać wyrażenie terytoria Tyru za określenie techniczne, odnoszące się do bardzo rozległego obszaru, skąd można było szybko udać się do Sydonu, to nie thumaczy jeszcze, dlaczego Jezus, planując powrót nad Jezioro Galilejskie, udaje się tam bardzo okrężną drogą przez terytoria Dekapolu położone na wschód i południowy wschód od jeziora. Hagiograf nie wymienia też miejscowości, które Jezus odwiedził. Oczywiście - teoretycznie taka trasa jest możliwa. Pewne kwestie, pojawiające się przy rekonstrukcji tej trasy i wydarzeń, jakie miały miejsce podczas podroży, budzą jednak wątpliwości. Trzeba sobie bowiem uświadomić, że w I wieku nie było bezpośredniej drogi z Sydonu nad Jezioro Galilejskie, choć istniała taka trasa z Tyru (Nineham 1969, s. 203). Ponadto rzucają się w oczy analogie, jakby lustrzane odbicie epizodów, które miały miejsce wcześniej na zachodnim lub północno-zachodnim wybrzeżu Jeziora Galilejskiego (Mk 6,33-7,37). Dlatego niektórzy bibliści traktują opis powrotnej podroży Jezusa jako pewien zabieg literacki służący celom teologicznym (McCown 2012, s. 5). Analogie przedstawia tab. 1.

To zestawienie pokazuje, że tylko spotkanie Jezusa z Syrofenicjanką (Mk 7,24-30) nie ma swojego odpowiednika. O ile opis wydarzeń rozgrywających się na zachodnim brzegu jeziora, na równinie Genezaret, odpowiada realiom topograficznym, o tyle przeniesienie analogicznych szczegółów na wschodni brzeg skutkuje opisami, które odbiegają od tych realiów. Za przykład niech posłuży Mk 6,45 oraz 8,10 . Naturalne i łatwe wydaje się przybicie łodzią, następnie jej zostawienie, a w końcu odbicie od łagodnego, zachodniego brzegu Jeziora Galilejskiego w okolicach równiny Genezaret, jak to sugeruje pierwszy opis. Opis drugi odnosi się do wydarzeń na wschodnim brzegu, najprawdopodobniej w okolicach Hippos i Kursi na terenie Dekapolu, gdzie brzeg jest stromy i wysoki. Warunki nie sprzyjają pozostawieniu łodzi przy brzegu, nie można też do niej wsiąść tak łatwo, jak sugeruje narracja (McCown 2012).

Jak powiedziano, zestawienie powyższych analogii zostało podyktowane celem teologicznym. Hagiograf chce w ten sposób pokazać swoim odbiorcom w większości nieżydowskiego pochodzenia, że misja Jezusa skierowana była zarówno do Żydów (zachodni brzeg), jak i do pogan (wschodni brzeg). Wszystko, cokolwiek Jezus robił dla Żydów, zostaje powtórzone w stosunku do pogan; zbawienie więc dotyczy jednych i drugich, a rozmowa z Syrofenicjanką, która wydaje się tu punktem kulminacyjnym, tezę tę potwierdza. Kompozycja tekstu podporządkowana teologii zdominowała realia topograficzne. 
Analogie opisów podróży w Mk 6 i Mk 8

\begin{tabular}{|l|c|c|}
\hline \multicolumn{1}{|c|}{ Zdarzenie } & $\begin{array}{c}\text { Zachodnie wybrzeże } \\
\text { Jeziora Genezaret }\end{array}$ & $\begin{array}{c}\text { Wschodnie wybrzeże } \\
\text { Jeziora Genezaret }\end{array}$ \\
\hline Unikanie napierającego tłumu & Mk 6,33 & Mk 8,1 \\
\hline $\begin{array}{l}\text { Tłum podążający za Jezusem i/lub } \\
\text { uczniami nie ma co jeść }\end{array}$ & Mk 6,35 & Mk 8,1-2 \\
\hline Pytanie o jedzenie & Mk 6,38 & Mk 8,6-9 \\
\hline $\begin{array}{l}\text { Rozmnożenie chlebów i ryb, } \\
\text { nakarmienie tłumów, zebranie resztek }\end{array}$ & Mk 6,45-52 & \\
\hline $\begin{array}{l}\text { Wyprawa łodzią do Betsaidy } \\
\text { (na północny wschód) }\end{array}$ & & Mk 8,10 \\
\hline $\begin{array}{l}\text { Wyprawa łodzią do Dalmanuty } \\
\text { (najprawdopodobniej na zachód) }\end{array}$ & Mk 7,1-22 & Mk 8,11-13 \\
\hline Kontrowersje z faryzeuszami & & \\
\hline
\end{tabular}

Źródło: opracowanie własne.

W tej części warto jeszcze zwrócić uwagę na dwie kwestie. Jedna dotyczy toponimii Dalmanuta, druga dookreślenia wspomnianej już wcześniej Betsaidy. W ewangeliach nazwa Dalmanuta występuje tylko w tym miejscu - Mk 8,10. Lokalizacja tego miejsca pozostaje niewiadomą. Określenie mere Dalmanoutha (część [o nazwie] Dalmanuta) sugeruje, że może chodzi o jakiś region, niekoniecznie o miejscowość. Niektóre rękopiśmienne świadectwa Ewangelii Marka mówią o terytorium (gr. horia) Dalmanuta, o górze (gr. horos) Dalmanuta, inne mówią o regionie Magdala lub Mageda (gr. mere Magdala; mere Mageda), jeszcze inne o regionie, terytorium Magada (gr. horia Magada) lub Melegada. Pewną wskazówką może być porównanie tego tekstu z paralelnym tekstem w Ewangelii Mateusza, który - jak już zauważono - często koryguje nieścisłości Marka. Mateusz (Mt 15,39) podaje, że po odprawieniu czterotysięcznego tłumu po drugim rozmnożeniu chleba, Jezus udał się łodzią w rejon Magadan na zachodnim brzegu Jeziora Galilejskiego. Wariantywną formą toponimii Magadan jest nazwa Magdala. Widać więc, że - podobnie jak miało to miejsce w przypadku Gerazy/Gadary/Gergezy - niektóre świadectwa starają się harmonizować informacje podawane przez obu ewangelistów. Niekiedy Dalmanutę identyfikuje się z grecką Taricheą, rybacką miejscowością wspominaną przez Józefa Flawiusza (Wojna żydowska III, 462-67), a później w Talmudzie w połączeniu z rzeczownikiem Migdal (Migdal Tarichea), od którego pochodzi nazwa Magdala (Edwards 2002, s. 234). Hipotezę tę zdają się, przynajmniej częściowo, potwierdzać odkrycia archeologiczne z 2013 roku, kiedy to w pobliżu Magdali, w dolinie Ginosar odnaleziono pozostałości architektoniczne oraz 
artefakty świadczące o istnieniu w tym miejscu dość bogatego miasta $\mathrm{z}$ łatwym dostępem do Jeziora Galilejskiego (por. Mk 8,13). Być może Marek w tym przypadku zastosował podobny zabieg, co przy Betsaidzie - zamiast greckiej nazwy użył nazwy semickiej, zwłaszcza że lokalizuje to miejsce po zachodniej, a więc ,żydowskiej” stronie jeziora.

Po dyskusji z faryzeuszami, Jezus opuścił Dalmanutę - wsiadt do łodzi i odplynąt na drugi brzeg $(\mathrm{Mk} 8,13)$. O tym, że „drugi brzeg” to tym razem północne wybrzeże Jeziora Galilejskiego, może świadczyć Mk 8,22: Potem przyszli do Betsaidy. Dalszy opis jest co najmniej zaskakujący, ponieważ Marek nazywa Betsaidę wsią - kome, tymczasem, jak powiedziano, w czasach Jezusa było to stosunkowo duże i znaczące zromanizowane miasto (Nineham 1969, s. 219). Można to thumaczyć na kilka sposobów, przyjąwszy diachroniczny lub synchroniczny kierunek egzegezy. Orientacja diachroniczna pozwala postawić tezę, że wiersz 22 i 23 należą do różnych warstw ewangelii. Ponieważ opis uzdrowienia niewidomego przypomina strukturalnie i leksykalnie opis uzdrowienia głuchoniemego (Mk 7,32-36), można przypuszczać, że oba opisy pochodzą $\mathrm{z}$ tego samego źródła lub jeden powstał na podstawie drugiego, a hagiograf (redaktor ewangelii) włączył je do swojego tekstu, dodając w zdaniach inicjalnych wzmianki topograficzne, które sprawiają wrażenie dość przypadkowych (7,31 i 8,22). Oznacza to, że wiersz 23 należy do tekstu źródłowego, natomiast wiersz 22 jest redakcyjnym dodatkiem o charakterze konektywnym.

Orientacja synchroniczna pozwala z kolei podkreślić wielokrotnie wspominaną już strategię wymieniania głównych miast jako punktów orientacyjnych dla odbiorców, którzy nie dość dokładnie znają geografię Palestyny. Markowi chodziłoby wtedy o zaznaczenie, że Jezus uzdrowił niewidomego, wyprowadzając go ze wsi leżącej w pobliżu Betsaidy ${ }^{11}$. W ten nurt wpisuje się również prowadzenie podporządkowanej teologii schematycznej narracji dotyczącej podróży Jezusa na północ (zachodni brzeg Jeziora Galilejskiego/Magdala/Dalmanuta Betsaida - Cezarea Filipowa) i wychodzenia przesłania o królestwie Bożym i zbawieniu od Żydów (Galilea/Dalmanuta) poprzez środowiska mieszane (wielonarodowościowa Betsaida w Gaulanitydzie) do pogan (Cezarea Filipowa niemal na granicy z Itureą). W te ramy zostają, niejako równolegle, wpisane różne przykłady ilustrujące ten progres: dyskusja i krytyka faryzeuszy $(8,11-15)$ oraz brak zrozumienia cudu rozmnożenia chleba $(8,16-21)$ - jako obraz niezrozumienia przesłania Jezusa przez Żydów; następnie stopniowe uzdrawianie niewidomego (Mk 8,23-25) - jako obraz coraz lepszego rozumienia tego przesłania przez uczniów; aż do uzyskania całkowitego poznania, kim jest Jezus i na czym polega Jego misja (Mk 8,27-9,1). Po raz kolejny widać, że elementy topograficzne są w Ewangelii Marka podporządkowane ideom teologicznym.

${ }^{11}$ Por. Mk 8,27, gdzie pojawia się precyzyjne wyrażenie tej samej idei: Jezus wraz z uczniami udat się do wiosek wokót Cezarei Filipowej. 


\section{Droga do Jerozolimy}

Trzecia część (Mk 9,2-11,11) - w porównaniu z niejasnymi i zawiłymi itinerariami części pierwszej i drugiej - jest zadziwiająco klarowna, choć też nie brakuje niedopowiedzeń. Marek np. nie podaje nazwy góry, na której dokonuje się przemienienie Jezusa - 9,2; dla ewangelisty jest to wysoka góra. Podobnie zresztą określają ją pozostali synoptycy (Łukasz pomija określenie „wysoka”). Czy mogła być to góra Tabor (588 m n.p.m.), na której według tradycji chrześcijańskiej dokonało się przemienienie Jezusa? Na to pytanie nie ma jednoznacznej odpowiedzi. Jednym z argumentów ,za" mogą być dane chronologiczne i poszlaki topograficzne. Marek bowiem twierdzi, że przemienienie miało miejsce po sześciu dniach (Mk 9,2) od wydarzeń pod Cezareą Filipową. Przez sześć dni Jezus i Jego uczniowie mogli przemierzyć trasę od Cezarei do góry Tabor leżącej w dolnej (południowej) Galilei. To by wyjaśniało, dlaczego wracając, przechodzili przez Galileę (Mk 9,30) i doszli do Kafarnaum położonego na północno-zachodnim brzegu Jeziora Galilejskiego ( $\mathrm{Mk}$ 9, 30). Ponadto greckie określenie horos hypselon (wysoka góra) może być bezpośrednim nawiązaniem do hebrajskiego har tabor, gdzie tabor - zgodnie z etymologią - oznacza coś podniesionego, a więc wysokiego (Koehler, Baumgarten, Stamm 2013, s. 623). Wątpliwości wiążą się z drugim dookreśleniem - kat' idian monous, które można tłumaczyć jako „osobno” i odnieść do towarzyszących Jezusowi uczniów - Piotra, Jakuba i Jana, którzy zostali „odosobnieni”, oddzieleni od pozostałych uczniów. Ale „osobno” może też odnosić się do okoliczności - wziąt ich [uczniów] na osobnośćc, czyli w miejsce ustronne. Biorąc pod uwagę fakt, że w I w. n.e. u stóp góry Tabor krzyżowały się szlaki handlowe (przebiegała tamtędy m.in. Via Maris do Damaszku), sama zaś góra stanowiła ważny punkt obserwacyjny i obronny (Rosik b.r.w. Tabor), trudno mówić o niej jako o miejscu ustronnym. Z kolei wzmianka o tym, że po zejściu $\mathrm{z}$ góry Jezus i trzej uczniowie ujrzeli wielki tlum $i$ uczonych $w$ Piśmie dyskutujących z pozostałymi uczniami (Mk 9,14), świadczy o tym, że w osadach $\mathrm{u}$ podnóża góry rzeczywiście toczyło się intensywne życie. W jednej z tych osad, oczywiście anonimowej, Jezus uzdrowił chłopca rzucającego się i wijącego po ziemi z pianą na ustach (Mk 9, 14-29) i stamtąd, przechodząc przez Galileę, udał się do Kafarnaum (Mk 9,30.33).

Jest też druga hipoteza związana z lokalizacją Markowej „wysokiej góry”. Miałaby to być góra znajdująca się stosunkowo niedaleko Cezarei Filipowej, ale na osobności i rzeczywiście wysoka. Takie kryteria spełnia góra, a właściwie masyw Hermon w górach Antylibanu. Wysokość Hermonu - 2814 m n.p.m. znacznie przewyższa wysokość góry Tabor. Przyjąwszy tę hipotezę, trudniej jest jednak połączyć opis przemienienia $\mathrm{z}$ opisem uzdrowionego chłopca w leżącej u stóp góry osadzie i wzmianką o przejściu przez Galileę, by zatrzymać się w Kafarnaum. Brak precyzyjnego wskazania na konkretną górę każe więc 
przypuszczać, że określenia wysoka oraz osobno/osobność mają charakter teologiczny, nie zaś topograficzny i nawiązują - podobnie zresztą jak temporalne po sześciu dniach - do scen z Wj 24,15-18, kiedy to Mojżesz na górze Synaj doświadcza teofanii i otrzymuje po raz drugi tablice z Dekalogiem.

Trasa dalszej wędrówki Jezusa wydaje się już prosta; z Kafarnaum Jezus drugim brzegiem Jordanu udat się do Judei (Mk 10,1). Mimo, że wiodąca wschodnim (drugim) brzegiem Jordanu trasa rzadko wybierana była przez pielgrzymów z Galilei, to jest ona zupełnie wiarygodna. Być może, jak wspomniano wcześniej, był to ten sam szlak przez Pereę z ominięciem Samarii, który wcześniej przeszli sami uczniowie (por. Mk 6,7-29). Nie ma tu również wielu wskazówek geograficznych, ale co jakiś czas powtarza się zwrot byli $w$ drodze do Jerozolimy (Mk 10,32.33). Tak przyszli do Jerycha (Mk 10,46). Jeśli przyjąć hipotezę wędrówki przez Pereę, to aby dostać się do Jerycha, trzeba przekroczyć Jordan. Marek o tym fakcie nawet nie wspomina, dlatego lokalizacja jakiegoś brodu, po którym można przejść, jest trudna. Być może były to brody w pobliżu Jerycha, może nawet to samo miejsce, w którym niegdyś Jan ochrzcił Jezusa.

Z Jerycha niemal prostą drogą Jezus i Jego uczniowie udali się do Jerozolimy, do Betfage i Betanii w pobliżu Góry Oliwnej (Mk 11,1). Jak widać, im bliżej Jerozolimy, tym Markowa topografia staje się bardziej konkretna i precyzyjna. Można $\mathrm{z}$ tego wnioskować, że te tereny były hagiografowi lepiej znane. Nie powinno to dziwić, jeśli przyjmie się tezę o jerozolimskim pochodzeniu Marka. Nieco wątpliwości wzbudza jedynie kolejność, w jakiej wymienione są miejscowości: Jerozolima, Betfage i Betania. Prymarną pozycję Jerozolimy można tłumaczyć zamiarem podkreślenia celu podróży. Pozostałe toponimy mają służyć doprecyzowaniu trasy. Ale skoro Jezus przywędrował do Jerozolimy z Jerycha, bardziej naturalną kolejnością byłoby wymienienie najpierw Betanii, a następnie Betfage, które znajdowało się nieco bliżej miasta. Tymczasem hagiograf wydaje się automatycznie przyjmować perspektywę mieszkańca Jerozolimy - dlatego najpierw wspomina o bliższym Betfage, a następnie o dalszej Betanii, a nie perspektywę pielgrzyma zmierzającego do miasta.

Z Betfage Jezus na osiołku wjeżdża do Jerozolimy i udaje się do świątyni (Mk 11,10). Jeszcze tego samego dnia opuszcza miasto i wraca do Betanii (Mk 11,11). Lakoniczne summarium nie pozwala stwierdzić, czy powrót nastąpił również przez Betfage, czy też z pominięciem tej wioski.

\section{Jerozolima}

Część czwarta (Mk 11,12-16,8) obejmuje ostatnie dni Jezusa w Jerozolimie i okolicy. Schemat działania Jezusa wydaje się taki sam, jak w części pierwszej. Tym razem miejscem zamieszkania i punktem, z którego Jezus kilkakrotnie podejmuje jednodniowe podróże do Jerozolimy, jest Betania (Mk 11,12.19.27; 14,3.13.17). Marek nie podaje odległości, jaka dzieliła Betanię i Jerozolimę, ale 
na podstawie danych z Ewangelii Jana (15 stadiów J 11,18) przyjmuje się, że wynosiła ona niecałe $3 \mathrm{~km}$.

Zadziwiające, że opis samej Jerozolimy jest w Ewangelii Marka bardzo oszczędny. Wydaje się, że hagiograf konsekwentnie podejmuje go z perspektywy mieszkańca miasta, dla którego rozmieszczenie poszczególnych obiektów jest oczywiste, dlatego tylko je wymienia. Prawdopodobnie również odbiorcy jego ewangelii, rzymscy żołnierze i oficerowie, znali topografię miasta. Część z nich mogła wcześniej nawet tam stacjonować; dodatkowe informacje nie były więc potrzebne. Najczęściej wspominanym obiektem jest świątynia, na terenie której lub w pobliżu Jezus nauczał. Z Mk 13,3 wynika, że była ona dobrze widoczna z Góry Oliwnej (818 m n.p.m.), naprzeciw której znajdowało się wzgórze świątynne. Zabudowania świątynne musiały być okazałe, skoro wzbudzały podziw uczniów (Mk 13,1). Choć świątynia jest na pewno dla Marka najważniejszym obiektem w Jerozolimie, to jednak nie stanowi ona żadnego punktu odniesienia dla lokalizacji innych budynków. Na podstawie samego tekstu nie można więc zrekonstruować układu architektonicznego miasta, dowiedzieć się, gdzie znajdował się wieczernik, ani gdzie dokładnie sytuować posiadłość (gr. chorion) Getsemane (Mk 14,32), choć pewne jest, że trzeba jej szukać poza murami miasta. Toponim grecki - Gethsemani jest nieco zniekształconym wariantem hebrajskiego - Gat Szemanim - ogród oliwek, co pozwala łączyć to miejsce z Górą Oliwną. Nie wiadomo, gdzie odbywał się sąd kapłanów i Wysokiej Rady nad Jezusem, bo typu dziedziniec najwyższego kapłana czy na dole na dziedzińcu nie pozwalają na precyzyjne wskazanie miejsca, świadczą tylko o tym, że budynki należały do ludzi zamożnych (Mk 14,53.66). Podobne uwagi dotyczą miejsca uwięzienia Jezusa przed wydaniem Go Piłatowi (Mk 15,1) i pretorium (Mk 15,10). Wiadomo natomiast, że Golgota, czyli Miejsce Czaszki znajdowała się poza miastem (Potem wyprowadzili Jezusa, aby Go ukrzyżować Mk 15,20), niedaleko publicznej drogi, skoro zmuszono powracającego z pola Szymona Cyrenejczyka do pomocy w dźwiganiu krzyża (Mk 15,21), w miejscu powszechnie dostępnym, skoro przechodzący urągali ukrzyżowanemu (Mk 15,29-32) i być może na jakimś niewielkim wzniesieniu, skoro kobiety mogły się temu przyglądać z daleka (Mk 15,40). Niewiele da się powiedzieć o miejscu pochówku Jezusa, jedynie to, że był to grób skalny.

Symboliczne, ale i nawiązujące do topografii poprzednich części jest zakończenie Ewangelii Marka. Młodzieniec, którego w grobie zastały kobiety, oznajmia im, że Jezus zmartwychwstał. Dostają też misję, aby powiedzieć uczniom, że Jezus wyprzedza ich do Galilei (Mk 16,7). W ten sposób hagiograf wiąże motyw początku misji Jezusa w Galilei z misją uczniów, która również powinna rozpocząć się w Galilei. Tzw. pośrednie zakończenie ewangelii ${ }^{12}$ - Potem sam

${ }^{12}$ Kodeksy najbardziej cenione przez biblistów - Synajski (a) i Watykański (B), oba z IV wieku, przekazują tekst kończący się na Mk 16,8. Zakończenie pośrednie pojawia się w kodeksie Y z góry Atos, pochodzącym z IX wieku. 
Jezus rozpowszechnit przez nich od wschodu na zachód święta i nieprzemijajaca nauke o wiecznym zbawieniu - zdaje się nawiązywać do dwutorowej, równoległej działalności Jezusa wśród Żydów na zachodnim wybrzeżu Jeziora Galilejskiego i wśród pogan na wybrzeżu wschodnim. Zakończenie dłuższe ${ }^{13}$ jest bardziej ogólnikowe i brakiem precyzji przypomina poprzednie części: nie wiadomo, gdzie gromadzą się uczniowie pogrążeni w smutku i płaczu, do których przychodzi Maria Magdalena (Mk 16,10), a potem Jezus (Mk 16,14). Czy pozostali w Jerozolimie, czy może w Betanii, tam, skąd wraz z Jezusem udawali się niemal codziennie do Jerozolimy? Sam Jezus ukazał się też dwom uczniom, którzy szli na pole lub na wieś. Użyty tu rzeczownik agros sugeruje, że nie chodzi o konkretną wieś (kome), lecz o miejsce, przestrzeń niezabudowaną, na której coś się uprawia. Można to rozumieć symbolicznie, jako nawiązanie do pierwszych, galilejskich przypowieści Jezusa o ziarnie, które pada na różne podłoża (Mk 4,1-8) i kiełkuje niezależnie od zabiegów i woli człowieka (Mk 4,26-29) lub o małym ziarnie gorczycy, które potężnie się rozrasta (Mk 4,30-32). Zostaje to podsumowane wezwaniem Idźcie na caly świat (Mk 16,15), bez specyfikacji, ale z wyraźną intencją ukazania uniwersalności oraz inkluzywności głoszonej Ewangelii. Tutaj znów geografia zostaje podporządkowana teologii i kompozycji całego tekstu.

\section{Podsumowanie}

Podsumowując, można powiedzieć, że wątki geograficzne Ewangelii Marka można rozpatrywać na kilku poziomach i z kilku perspektyw. Na poziomie weryfikacji danych i rekonstrukcji podróży misyjnych Jezusa, na podstawie tekstu da się zauważyć wiele nieścisłości, lakoniczność, ogólnikowość i pewien chaos. Jeśli weźmie się pod uwagę perspektywę odbiorców, do których ewangelia została skierowana, da się to wytlumaczyć dostosowaniem przekazu do kompetencji adresatów. Inaczej wygląda to na poziomie kompozycyjnym tekstu i jego przesłania teologicznego. Wydaje się bowiem, że - mimo pozornego chaosu, lakoniczności, niedookreśloności i ogólności - topografia Ewangelii Marka jest przemyślana, choć nie wszędzie w takim samym stopniu. O ile w części pierwszej, a zwłaszcza drugiej, dominantę stanowi przesłanie teologiczne i jemu podlegają inne komponenty ewangelii, o tyle w części trzeciej symboliczne odczytanie motywów geograficznych pojawia się rzadziej. Im bliżej Jerozolimy, tym topografia staje się coraz bardziej konkretna i zgodna $\mathrm{z}$ realiami panującymi w I w. n.e., co z jednej strony utrudnia nadanie jej symbolicznego wymiaru, z drugiej ułatwia linearne odtworzenie trasy przebytą przez Jezusa

${ }^{13}$ Zakończenie dłuższe - Mk 16,9-20 - zawierają m.in. kodeksy: Aleksandryjski (A), Efrema (C), Bezy (D), Waszyngtoński (W), wszystkie z V wieku, oraz Cypryjski (K) z IX wieku., Regius (L) z VIII wieku, Coridethi (Q) z IX wieku. 
z Galilei do Jerozolimy. Najmniej symbolicznych akcentów topograficznych znajduje się w passusach opisujących mękę i śmierć Jezusa. Powracają one w zakończeniu wraz z ogólnikową i uniwersalistyczną leksyką, którą można odnosić zarówno do przedstawionych wcześniej treści szczegółowych, jak i do głównego przesłania teologicznego o inkluzywizmie i egalitarności dobrej nowiny o zbawieniu.

\section{LITERATURA}

Briks P., 2004, Betsaida w Biblii i najnowszych badaniach archeologicznych, „Studia Judaica”, 7, nr 1(13).

Czerski J., 2003, Księgi narracyjne Nowego Testamentu. Wprowadzenie historyczno-literackie i teologiczne, Redakcja Wydawnictw WT UO, Opole.

Edwards J.R, 2002, The Gospel according to Mark, PNTC, Eerdmans, Grand Rapids.

Funk R.W. et al., 1998, The Acts of Jesus: What Did Jesus Really Do?, Polebridge, Salem.

Incigneri B.J., 2003, The Gospel to the Romans. The Setting and Rhetoric of Mark's Gospel, Brill, Leiden.

Kee H.C., 1977, Community of the New Age: Studies in Mark's Gospel, SCM Press London.

Koehler L., Baumgarten W., Stamm J.J, 2013, Wielki stownik hebrajsko-polski i aramejsko-polski Starego Testamentu, t. 2, Vocatio, Warszawa.

Langkammer H. (red.), 1977, Ewangelia wedtug św. Marka, Pallotinum, Poznań-Warszawa.

McCown C.C., 2012, Gospel Geography. Fiction, Fact and Truth, JBL 60/1.

Nineham D.E., 1969, Saint Mark, Penguin, Baltimore.

Rosik M., b.r.w., Macheront, http://wroclaw.biblista.pl/index.php?option=com_content \&view=article\&id=407:macheront\&catid=40:ze-sowem-w-codzienno\&Itemid=83 (dostęp: 6.06.2015).

Rosik M., b.r.w., Tabor - Góra Przemienienia http://wroclaw.biblista.pl/index.php? option=com_content\&view=article\&id=340\%3Atabor-gora-przemienienia\&catid= 40\%3Aze-sowem-w-codzienno\&Itemid=83 (dostęp: 6.06 .2015 ).

Theissen G., 1992, The Gospels in context: Social and political history in the synoptic tradition, Fortress, Minneapolis.

Wojciechowska K., 2006, Opowiadam wam jak Piotr. Elementy stylu i stylizacji w Ewangelii Marka, Wydawnictwo Naukowe ChAT, Warszawa.

Wojciechowski M., 2010, Cuda Jezusa, Edycja św. Pawła, Częstochowa.

\section{THE GEOGRAPHICAL HORIZON OF MARK’S GOSPEL}

Abstract: This article reconstructs the picture of the movements of Jesus since John's baptizing until the journey to Jerusalem. There are geographical and chronological problems connected with the Gospel of Mark. In many instances the evangelist does not know where and when incidents took place. The topographical data are likewise 
confused and contradictory. The evangelist emphasizes the contrast between the apparent aimlessness of Jesus' movements and ministry in the earlier period in Galilee (Mk 1:1-6:29) and the plan of the later periodes. In second part (Mk 6:30-9:1) Mark possessed two divergent but paralel accounts of the events following the return of the Twelve. The third part (Mk 9:2-11:11) is the journey of Jesus from Cesarea Philippi to Jerusalem, and the fourth part are the evants in Jerusalem. In Jerusalem Mark's topographical notations are also never detailed and informative.

Key words: Gospel of Mark, topography, Galilee, Judee, Capernaum, Tyre, Sidon, Gerasa, Sea of Galilee, Jesus, mission, Jerusalem, Jordan.

Dr hab. Kalina Wojciechowska, prof. ChAT Katedra Wiedzy Nowotestamentowej i Języka Greckiego Wydział Teologiczny Chrześcijańska Akademia Teologiczna w Warszawie 